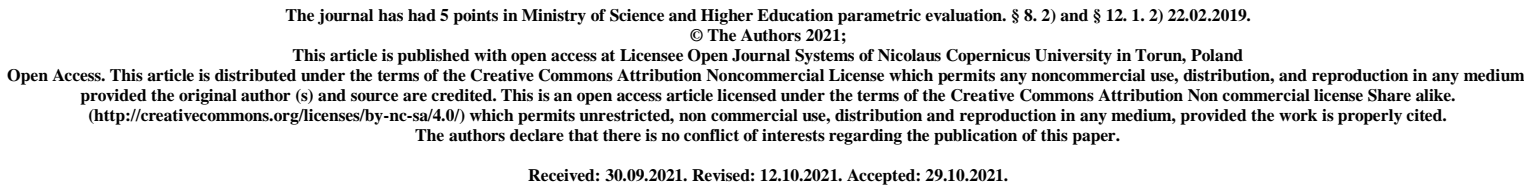

UDC: 616.314.18-002.4-099:612.76]-092.9

\title{
Evaluation of endogenous intoxication indicators in the dynamics of experimental periodontitis and immobilization stress
}

\section{P. V. Olekshij}

\section{Lviv Medical Institute}

\section{Abstract}

The aim of our work was to investigate the peculiarities of changes in endogenous intoxication rates: medium mass molecules (MMM) and erythrocyte intoxication index (EII) in the blood of guinea pigs in the formation of combined pathology - experimental periodontitis (EP) and immobilization stress (IS).

The results of biochemical studies showed that at all stages of development of combined pathology - experimental periodontitis and immobilization stress there is a consistent increase in the degree of endogenous intoxication, which dominated on the $15^{\text {th }}$ day of the experiment, namely increased content of medium mass molecules $\left(\mathrm{MMM}_{254}\right.$, $\left.\mathrm{MMM}_{280}\right)$ and EII in the blood by $58.5 \%(\mathrm{p} \leq 0.05), 80.3 \%(\mathrm{p} \leq 0.05)$ and $95.7 \%(\mathrm{p} \leq 0.05)$, respectively, compared with the first group of animals is a clear manifestation of the formation of endogenous intoxication. These changes are obviously the result of insufficient elimination of toxic products on the background of the inflammatory process in periodontal tissues and stress.

Key words: periodontitis; stress; endogenous intoxication. 


\title{
Оцінка показників ендогенної інтоксикації в динаміці розвитку експериментального парадонтиту та іммобілізаційного стресу
}

\author{
П. В. Олекшій
}

\section{Львівський медичний інститут}

Метою нашої роботи було дослідити особливості зміни показників ендогенної інтоксикації: молекул середньої маси (MCM) та еритроцитарний індекс інтоксикації (EII) у крові морських свинок при формуванні комбінованої патології експериментального пародонтиту (ЕП) і іммобілізаційного стресу (IC).

Результати біохімічних досліджень показали, що на усіх етапах розвитку поєднаної патології - експериментального пародонтита та іммобілізаційного стресу відбувається послідовне зростання ступеня ендогенної інтоксикації, яке домінувало на 15-у добу експерименту, а саме підвищувався вміст молекул середньої маси $\left(\mathrm{MCM}_{254}\right.$, $\mathrm{MCM}_{280}$ ) і еритроцитарного індексу інтоксикації (ЕІІ) в крові відповідно на 58,5 \% $(\mathrm{p} \leq 0,05), 80,3 \%(\mathrm{p} \leq 0,05)$ і 95,7 \% $(\mathrm{p} \leq 0,05)$ в порівнянні 3 першою групою тварин, що $€$ яскравим проявом формування ендогенної інтоксикації. Ці зміни очевидно, є наслідком недостатньої елімінації токсичних продуктів на тлі запального процесу в тканинах пародонта і стресу.

Ключові слова: пародонтит; стрес; ендогенна інтоксикація.

Оценка показателей эндогенной интоксикации в динамике развития экспериментального пародонтита и иммобилизационного стресса

\section{П. В. Олекший}

\section{Львовский медицинский институт}

Целью нашей работы было изучить особенности изменения показателей эндогенной интоксикации: молекул средней массы (MCM) и эритроцитарного индекса интоксикации (ЭИИ) в крови морских свинок при формировании комбинированной 
патологии - экспериментального пародонтита (ЭП) и иммобилизационного стресса (ИС).

Результаты биохимических исследований показали, что на всех этапах развития сочетанной патологии - экспериментального пародонтита и иммобилизационного стресса происходит последовательный рост степени эндогенной интоксикации, которое доминировало на 15-е сутки эксперимента, а именно повышалось содержание молекул средней массы $\left(\mathrm{MCM}_{254}, \mathrm{MCM}_{280}\right)$ и ЭИИ в крови соответственно на $58,5 \%(\mathrm{p} \leq 0,05)$, $80,3 \%(p \leq 0,05)$ и 95,7\% (p $\leq 0,05)$ по сравнению с первой группой животных, является ярким проявлением формирования эндогенной интоксикации. Эти изменения являются следствием недостаточной элиминации токсических продуктов на фоне воспалительного процесса в тканях пародонта и стресса.

\section{Ключевые слова: пародонтит; стресс; эндогенная интоксикация.}

The problem of periodontitis remains relevant for modern dentistry. The study of the pathogenesis of this disease is extremely important today.

It is known from the literature that various diseases are accompanied by the development of endogenous intoxication syndrome (EI) [1]. Endogenous toxins determine the features of the clinical course and prognosis of the underlying disease. Infectious inflammatory process, which includes generalized periodontitis, is always accompanied by a violation of metabolic homeostasis [4]. In this pathology there is endotoxemia, which disrupts the tone of peripheral vessels, blood rheology, kinetic and mechanical properties of the formed elements of the blood, which leads to the development of hypoxia. Endogenous intoxication can be considered one of the most important criteria that determines the severity of the patient's condition [5].

In the practical work of the doctor there are often cases of combined periodontal pathology and comorbidities that aggravate and change the clinical course of the underlying disease.

Therefore, the aim of our work was to investigate the peculiarities of changes in endogenous intoxication rates: medium mass molecules (MMM) and erythrocyte intoxication index (EII) in the blood of guinea pigs in the formation of combined pathology - experimental periodontitis (EP) and immobilization stress (IS).

Material and methods of research. Experimental studies were performed on 40 guinea pigs (males), weighing $0.18-0.21 \mathrm{~kg}$, kept on the standard diet of the vivarium of 
Danylo Halytsky Lviv National Medical University. Guinea pigs were divided into four groups (10 in each): the first - intact animals - control; the second (experimental) group animals with experimental periodontitis and immobilization stress ( $3^{\text {rd }}$ day), the third group included guinea pigs with EP and IS on the $5^{\text {th }}$ day of the combined model process, to IV animals with EP and IS on the $15^{\text {th }}$ day.

Experimental periodontitis was modeled by the method of ZR Jogan (1983) [3]. Immobilization stress was reproduced by the method of PD Horizontov (1996) [2]. We selected fixed days $\left(3^{\text {rd }}, 5^{\text {th }}\right.$ and $\left.15^{\text {th }}\right)$ for studies that corresponded to the classic stages of acute inflammation. All experiments on laboratory animals carried out with following the European Convention for the protection of vertebrate animals used for experimental and other scientific purposes (Strasbourg, 1986), Council Directive 2010/63 / EU, the Law of Ukraine 3447- IV "protection animals from the cruelty," the general ethics of animal experimentation adopted by the first national Congress on bioethics in Ukraine (2001).

The study material was collected under ether anesthesia. In all groups of guinea pigs there were determined the MMM concentration in blood in the wave of $254 \mathrm{~nm}$ and $280 \mathrm{~nm}$ by IA Volchehorskiy, DA Dyatlova, EI Lvovska and others methods [7] and EII by DK Shmojlova methods [6]. Numerical results were adapted with static method using Student's criteria.

Results of the study and their discussion.A fairly accurate criterion for the presence and severity of the syndrome of "metabolic intoxication" in the body is the concentration of MMM in the blood of patients [5].

The results of $\mathrm{MSM}_{254}$ studies showed an increase in their content during all the studied days of EP and IS, namely an growth on the $3^{\text {rd }}, 5^{\text {th }}$ and $15^{\text {th }}$ days by $51.8 \%, 53.6 \%$ and 58,5\% ( $\leq 0.05)$, respectively, when compared with the control (Fig. 1).

Continuing the study of $\mathrm{MMM}_{280}$, we observe a similar vector of changes with even more significant growth on the $15^{\text {th }}$ day of the experiment. Thus, the $3^{\text {rd }}$ day increased the content of $\mathrm{MMM}_{280}$ in the blood by $55.4 \%(\mathrm{p} \leq 0.05)$ against intact animals. Continuing the study of this test in the blood of the third and fourth groups of guinea pigs with EP and IS, further changes were shown, which deepened even more and were unidirectional: the growth of $\mathrm{MMM}_{280}$ was observed by $62.3 \%(\mathrm{p} \leq 0.05)$ and $80,3 \%(\mathrm{p} \leq 0.05)$ compared with the first group of animals (Fig. 1). 


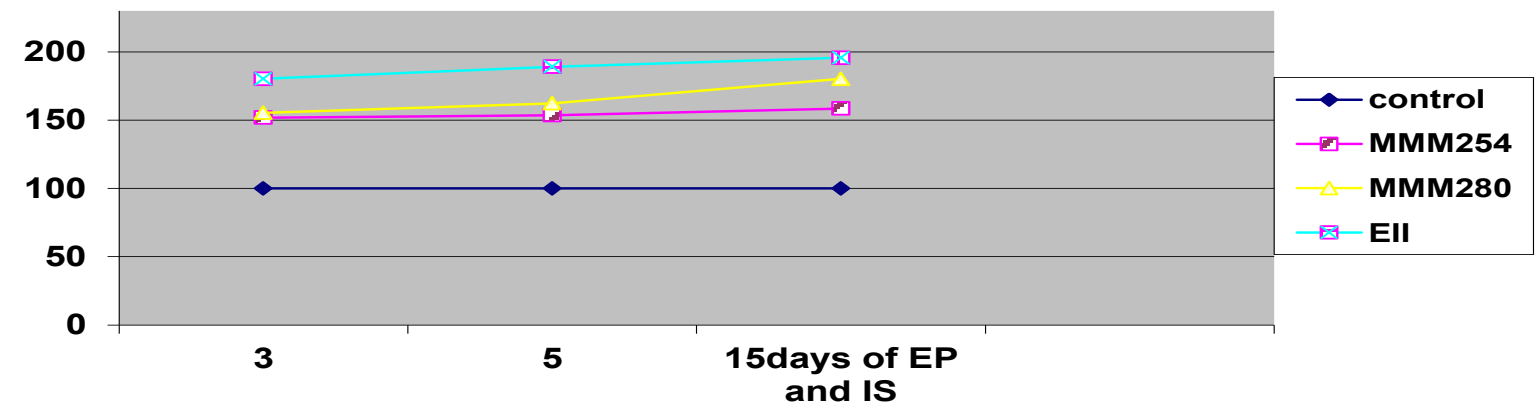

Fig.1 - The level of endogenous intoxication in the blood of guinea pigs in the dynamics of the formation of EP and IS (\% of control)

Another important criterion for endogenous intoxication is the erythrocyte intoxication index. The results of studies of this marker showed that EII is characterized by a significant increase on the $3^{\text {rd }}$ day of EP and IS, namely by $80.3 \%(\mathrm{p} \leq 0.05)$ compared with control values. This rate of endogenous intoxication increased on the $5^{\text {th }}$ and $15^{\text {th }}$ days by $89.1 \%$ $(p \leq 0.05)$ and $95.7 \%(p \leq 0.05)$, respectively, against the first group of animals (Fig. 1).

Conclusions. The results of biochemical studies showed that at all stages of development of combined pathology - experimental periodontitis and immobilization stress there is a consistent increase in the degree of endogenous intoxication, which dominated on the $15^{\text {th }}$ day of the experiment, namely increased content of medium weight molecules $\left(\mathrm{MCM}_{254}, \mathrm{MMM}_{280}\right)$ and EII in the blood by $58.5 \%(\mathrm{p} \leq 0.05), 80.3 \%(\mathrm{p} \leq 0.05)$ and $95.7 \%$ $(\mathrm{p} \leq 0.05)$, respectively, compared with the first group of animals. It is a clear manifestation of the formation of endogenous intoxication. These changes are obviously the result of insufficient elimination of toxic products on the background of the inflammatory process in periodontal tissues and stress.

\section{References}

1. Bondarchuk V.I. Zmina pokaznykiv endohennoyi intoksykatsiyi ta humoral'noho imunitetu pry vplyvi riznykh typiv zapal'noyi reaktsiyi tvaryn z hastroduodenitom. Visnyk naukovykh doslidzhen', 2015. №3. 107-109. (in Ukrainian) 
2. Gorizontov PD, Belousov OI, Fedotov MI Stress i systema krovi. M.: Medicine, 1983.p.338. (in Russian)

3. Jogan ZR Clinico-experimentalne obosnovanie usovershenstvovania orthopedichnyx metodiv pry complexnomu likuvanni chvorob parodonta. Author's ref. Dis. Candidate of Medical Sciences, Kyiv, 1996. p.18. (in Ukrainian)

4. Kolishetska MA Characteristic of individual indicators of endogenous intoxication in the experimental asthma dynamics and their correction by thiotriazolin. EUREKA : Health Sciences. 2016. Vol. 6, № 6. P. 52-56. (in English)

5. Regeda-Furdychko M M The level of endogenic intoxication in the dynamics of development o fexperimental contact dermatitis and experimental pneumonia and their correction by thiotriazoline. Journal of Education, Health and Sport. 2019;9(11):287-292. (in English)

6. Shmoilov DK, Karimov IZ, Odynets TN. (2012). Pathogenic role of endogenous intoxication. Lab. Diagnostic, 2, 65-69. (in Russian)

7. Volchegorskiy IA, Diatlov DA, Lvovskaya EI et. al. (1997). Middle molecules" as probable regulators of erythrone system in skiers. Lab. Diagnostic, 1, 11-16. (in Russian) 